chief editor of the Journal of Microscopical Science, and bearing other responsibilities, he worthily held the most prominent position of his day in biology, and the loss of so capable a man and so genial a friend is deeply felt.

W. C. M'Intosh.

\section{Sir W. Baldwin Spencer, K.C.M.G., F.R.S.}

THIs is written away from books and other aids to memory, and must be taken for what it is, not a biographical sketch but rather an appreciation. Baldwin Spencer graduated at Exeter College, Oxford, and has for many years past been one of our honorary fellows; so I was in the way of seeing him whenever he was in England. Again, on a visit to Australia with the British Association in $1914 \mathrm{I}$ had the chance of observing him at work among the countless treasures with which his explorations had enriched the Melbourne Museum.

About his personality I need say no more than that Spencer himself was more inspiring even than his books. He had all the traits of the first-rate man of science-faithfulness to fact, cool and penetrating judgment, hatred of humbug and half-truths, and, above all, a forcefulness and courage that made him not only conceive noble schemes of research but also carry them out at all costs to a finish. Alas ! his own end among the rigours of Tierra del Fuego is proof enough of an intrepidity verging on recklessness. I had a letter from him written from that desolate spot very shortly before his death, in which there is not the slightest hint of danger ahead, and every word betrays the enthusiasm provoked by the prospect of good hunting. Though his voyage out in a cargo-boat (on which he had to sign on as purser to get a passage) cannot have been altogether luxurious, he makes light of it. Indeed, his only complaint, if it can be reckoned one, is that the Argentine authorities insisted on his maternal cognomen being tacked on to the paternal 'Spencer' -a fact that reminds him, he says, of the fact that the matrilineal system is not confined to aboriginal Australia.

Now as to the inspiration that all of us have received from Spencer's books. It is no exaggeration to say that "The Native Tribes of Central Australia ", when it appeared in the late 'nineties, gave a new orientation to social anthropology. The biologist of the Horn Expedition of 1894 to the Central region had soon discovered that nothing among the rest of the fauna could compete in interest with man, and, fortified by the local knowledge of Mr. F. J. Gillen, had produced a monograph that exhibited Stone age mentality as something almost sui generis, so utterly did its processes differ from those of civilised humanity. Soon Sir James Frazer had got to work on the new facts, and it would scarcely be unfair to say that for him, henceforth, primitive man meant first and foremost the Arunta. So it was with the rest of us. I have numerous letters of that period from Andrew Lang which-though he by no means saw eye to eye with Sir James Frazer on questions of theory-are equally obsessed with the Central
Australians as the real thing at last, the human prototype as near as we shall ever meet him in the flesh.

Spencer's further accounts of the North-Central tribes and of those of Northern Territory proved no less sound, if a little less startling, since they revealed what were essentially the same conditions - namely, totemism and a type of cult which some would call magic, others rudimentary religion, the two in close conjunction and permeating every department of the native life.

It may be added by way of testimony to the conscientiousness of Spencer as a man of science that recently he has revised his whole study of the Arunta, correcting linguistic slips and more especially seeking to make allowance for the fact that Gillen and he were in closer touch with one part of the tribe, or rather nation, than with the restthe total result, however, being to confirm the fundamental accuracy of the original presentation. His works will survive alike on account of their unique contents and because they are models of scientific method. A great man has passed away suddenly, even tragically. But, mourning him, his many friends will be consoled to think that what he wrought will not pass away; for he wrought as a master.

R. R. MARETT.

WE much regret to announce the death at Washington of Mr. Emile Berliner, one of the inventors of the microphone and the inventor of the gramophone. Born in Hanover on May 20, 1851, Berliner migrated to America in 1870 and became a salesman in Washington, and it was there in 1876 that he began experimenting with Bell's recently invented telephone. The following year, almost simultaneously with Edison, he brought out his device for varying the electric current by varying the pressure between two contact points, and many years later the Supreme Court of the United States declared Berliner to have been the original inventor of the transmitter. Berliner's next notable invention was the gramophone. Edison's phonograph, patented in 1878, included wax cylinder records cut by an engraving tool which rose and fell-the ' hill and dale' method. Berliner employed dises which were engraved by a tool which vibrated from side to side-the 'lateral cut' method. His patent was taken out in 1887, and his original machine was exhibited in the Franklin Institute on May 16, 1888 ; it is now in the National Museum, Washington. Berliner also devoted himself to the improvement of the acoustic properties of public buildings, and in 1907 brought out a revolving cylinder internal combustion engine for aircraft.

WE regret to announce the following deaths:

Dr. T. J. I'A. Bromwich, F.R.S., formerly fellow and prælector in mathematical science at St. John's College, Cambridge, and University lecturer in mathematics, on Aug. 24, aged fifty-four years.

Prof. S. B. Schryver, F.R.S., professor of biochemistry at the Imperial College of Science and Technology, on Aug. 21, aged sixty years.

$$
\text { No. } 3122 \text {, VoL. 124] }
$$

